\title{
Electronic Word of Mouth (E-Wom) of Transportation Application Consumers in Indonesia: Which Factors That Are Matter
}

\author{
Leonnard ${ }^{1}$, Etty Susilowati ${ }^{2}$ \\ ${ }^{1}$ Sekolah Tinggi Manajemen IPMI, ${ }^{2}$ University of Budi Luhur \\ 1leonnard.ong@ipmi.ac.id, ${ }^{2}$ ettysslwt@gmail.com
}

\begin{abstract}
Transportation applications are now becoming a popular means of transportation in major cities of developing countries. This is because high levels of community mobility are faced with high levels of congestion. This study was constructed to test the effect of service quality to e-WOM through consumer satisfaction by using PLS SEM-path modeling. Empirical findings indicated that all hypotheses tested are proven. Service quality had a significant positive effect directly on satisfaction and indirectly against $e$-WOM. Subsequently, from the service quality indicator, the most influential indicator was the driver interaction with the consumer. These findings were different from public transportation, which did not employ online application where indicator tangibles had the highest effect that create consumer perception of service quality. Discussion and managerial implications are provided.
\end{abstract}

Keywords: electronic word of mouth, transportation application, satisfaction.

\begin{abstract}
Abstrak
Aplikasi sepeda motor kini menjadi sarana transportasi yang populer di kota-kota besar di negaranegara berkembang. Hal ini karena tingginya tingkat mobilitas masyarakat dihadapkan pada tingginya tingkat kemacetan. Penelitian ini dilakukan untuk menguji pengaruh kualitas layanan terhadap e-WOM melalui kepuasan konsumen dengan menggunakan PLS SEM-path modeling Temuan empiris menunjukkan bahwa semua hipotesis yang diuji terbukti. Kualitas layanan memiliki pengaruh positif yang signifikan secara langsung terhadap kepuasan dan tidak langsung terhadap e-WOM. Selanjutnya, dari indikator kualitas layanan, indikator yang paling berpengaruh adalah interaksi pengemudi dengan konsumen. Temuan ini berbeda dengan transportasi umum yang tidak menggunakan aplikasi online dimana indikator fasilitas fisik memiliki pengaruh tertinggi yang membentuk persepsi konsumen terhadap kualitas layanan. Hasil penelitian ini ditutup dengan diskusi dan implikasi manajerial.
\end{abstract}

Kata kunci: electronic word of mouth, aplikasi transportasi, kepuasan.

\section{Cara Mengutip:}

Leonnard., \& Susilowati, E. (2018). Electronic Word of Mouth (E-Wom) of Transportation Application Consumers in Indonesia: Which Factors That Are Matter. Esensi: Jurnal Bisnis dan Manajemen. Vol. 8 (1): 79 - 88. doi: 10.15408/ess.v8i1.6708. 


\section{INTRODUCTION}

Nowadays, motorbike taxi applications are becoming a popular choice of transportation services, especially in big cities. This is because the high level of mobility is faced with high levels of congestion, therefore the presence of motorbike taxi applications that provide inter-service and pick up passengers, which are on average faster than using other public transportation and private cars becomes very popular. In addition, additional services in the form of ease of ordering, payment transactions and rewards from the company in the form of points through mobile money payment become an attraction for people who want their mobility made quickly and easily.

Although the online app transportation system is set up by using an online network, the level of customer satisfaction mainly depends on the service quality provided by drivers when interacting with consumers. The ability of drivers in providing service quality according to company standards and according to customer expectations will provide satisfaction who will ultimately affect consumers to spread a positive impression about the experience of using the service, vice versa.

The positive or negative impression becomes very crucial nowadays with the presence of social media and chat groups that make the flow of information becomes very fast (Duan et al, 2008). Negative impression spreads even faster through social media and chat groups than positive impression (Reimer \& Benkenstein, 2016). Therefore, it is very important for the company to ensure that the service quality provided by the drivers and the company in accordance with the needs of consumers. The ability of companies to understand the factors that affect e-WOM of motorbike taxi consumers will help managers make the right marketing strategy to maintain and increase their customers. Therefore, in this study, we analyze which of the types of service quality that most influence consumers in spreading their impression through social media and chat groups in Indonesia and how it relates to satisfaction and e-WOM.

Studies on service quality of transportation services had been carried out previously. However, the type of transportation services was limited to airlines, buses and trains (Mahmoud \& Hine, 2016; Carreira et al, 2014; Chou et al, 2014; Lai \& Chen, 2011), while the service quality analysis on motorbike taxi applications is still very rare considering the presence of this transportation is still relatively new. Most of studies on e-WOM were analyzed for types of intangible services such as hospitals (Abubakar et al., 2017), hotels (Ladhari \& Michaud, 2015, Tsao et al., 2015), and higher institutions (Li and Wang, 2013). The results of this study are expected to enrich literatures of service quality of online based transportation services and its effect on e-WOM. The findings of this study are supposed to provide knowledge in term of the effect of service quality and its relation to satisfaction and e-WOM on online based transportation services and whether the effects are similar or not to other transportation services which are not based on online applications.

\section{METHOD}

Data were collected through direct interviews using questionnaires to 75 consumers of motorbike taxi application in Tangerang City, Indonesia. Tangerang is one of the big 
cities in Indonesia. Questionnaires were employing Likert scale (1 = strongly disagree, 2 = disagree, 3 = agree, 4 = strongly agree). The data were then processed using PLS SEM-path modeling through SmartPLS 3 statistical package software.

The indicators employed to measure service quality in this study are based on the indicators used in public transportation services from previous studies. Because the motorbike taxi application is a relatively new kind of transportation services and has not been widely studied, there is no guidance on indicators that have been used before. Table 1 indicates that safety and security are widely used indicators (Lai \& Chen, 2011; Chou et al, 2014; Carreira, et al., 2014; Mahmoud \& Hine, 2016), followed by information and facilities (Mahmoud \& Hine, 2016; Carreira et al., 2014; Lai \& Chen, 2011), tangible (Şimşekoğlu et al, 2015; Chou et al, 2014; Jiang \& Zhang, 2016; Gupta, 2017), convenience (Şimşekoğlu et al, 2015; Carreira et al., 2014; Chou et al, 2014); and access to service (Mahmoud \& Hine, 2016; Carreira et al., 2014; Lai \& Chen, 2011).

Table 1. Measurement of Service Quality from Prior Literatures

\begin{tabular}{|c|c|c|c|c|c|c|c|}
\hline $\begin{array}{l}\text { Service quality } \\
\text { indicators }\end{array}$ & $\begin{array}{l}\text { Mahmoud } \\
\text { and Hine, } \\
2016 \text { (BUS) }\end{array}$ & $\begin{array}{l}\text { Simsekoglu, } \\
\text { Nordfjaern, } \\
\text { and Rundmo, } \\
2015 \text { (PUBLIC } \\
\text { TRANSPORT) }\end{array}$ & $\begin{array}{l}\text { Carreira, } \\
\text { et al., } \\
2014 \\
\text { (BUS) }\end{array}$ & $\begin{array}{c}\text { Chou, Lu, } \\
\text { and Chang, } \\
2014 \\
\text { (TRAIN) }\end{array}$ & $\begin{array}{c}\text { Jiang \& } \\
\text { Zhang (2016), } \\
\text { Gupta (2017), } \\
\text { (AIRLINE) }\end{array}$ & $\begin{array}{l}\text { Lai and Chen, } \\
2011 \text { (PUBLIC } \\
\text { TRANSPORT) }\end{array}$ & $\begin{array}{c}\text { Hosseini, Zadeh, \& } \\
\text { Bideh, 2013 } \\
\text { (MOBILE } \\
\text { TELECOMMUNICATION } \\
\text { SERVICE QUALITY) }\end{array}$ \\
\hline Service design & v & & & & & & \\
\hline Access to service & v & & v & & & v & \\
\hline Operation & v & & & & & & \\
\hline $\begin{array}{l}\text { Information and } \\
\text { facilities }\end{array}$ & v & & v & & & v & \\
\hline Fare & v & & & & & & \\
\hline Safety and security & v & & v & v & & v & \\
\hline Tangible & & v & & v & v & & \\
\hline Convenience & & v & $\mathrm{v}$ & $\mathrm{v}$ & & & \\
\hline $\begin{array}{l}\text { Personal } \\
\text { interaction }\end{array}$ & & & & v & $\mathrm{v}$ & v & \\
\hline Cleanlines & & & v & & & v & \\
\hline Personal skill & & & v & & & & \\
\hline $\begin{array}{l}\text { Visibility of the } \\
\text { scenery }\end{array}$ & & & $\mathrm{v}$ & & & & \\
\hline Waiting time & & & v & & & & \\
\hline $\begin{array}{l}\text { On-board } \\
\text { entertainment }\end{array}$ & & & v & & & v & \\
\hline Off-board services & & & $\mathrm{v}$ & & & v & \\
\hline Social environment & & & v & & & & \\
\hline Complaint dealing & & & & & & v & \\
\hline Flexibility & & v & & & & & \\
\hline Reliability & & & & & v & & \\
\hline Responsiveness & & & & & v & & \\
\hline Assurance & & & & & v & & \\
\hline \multicolumn{8}{|l|}{ Empathy } \\
\hline $\begin{array}{l}\text { Value-added } \\
\text { services }\end{array}$ & & & & & $\mathrm{v}$ & & $v$ \\
\hline
\end{tabular}


Based on the identification, in this study, we employed indicators of facilities, safety, convenience, personal interaction, personnel skills, cleanliness and value-added services. The value-added service indicators are used in addition to the use of mobile telecommunication to order, rate, earn points and make payments on motorbike taxi applications.

\section{Table 2. The Questionnaire Items}

\begin{tabular}{|c|c|c|}
\hline No & Indikator & Item kuisioner \\
\hline \multirow[t]{3}{*}{1} & Cleanliness & The motorbike is clean \\
\hline & & Other facilities provided by the driver are clean \\
\hline & & The driver is clean \\
\hline \multirow[t]{2}{*}{2} & Convenience & The facilities provided by the driver are convenient \\
\hline & & The way how the driver drive the motorbike make me comfortable \\
\hline \multirow[t]{4}{*}{3} & Facilities & The motorbike is in a good condition \\
\hline & & The driver provide other facilities \\
\hline & & The other facilities provided by the driver are in good conditions \\
\hline & & The facilities provided are complete \\
\hline \multirow[t]{8}{*}{4} & Personal interaction & The driver appearance is neat \\
\hline & & The driver looks healthy \\
\hline & & The driver is friendly \\
\hline & & The driver responds quickly when I call asking for his position \\
\hline & & The driver is in the prime state \\
\hline & & The driver adjusts to my desire to drive the motorbike \\
\hline & & The driver help lift my stuff \\
\hline & & The driver is able to answer my questions during the trip \\
\hline \multirow[t]{2}{*}{5} & Safety & The facilities provided by the driver are safe to use \\
\hline & & The drivers focus on driving the motorbike \\
\hline \multirow[t]{6}{*}{6} & Personal skill & The ability of the driver to drive a motorbike is trusted \\
\hline & & The driver is able to find the exact pickup location \\
\hline & & The driver is able to drive me to the right location \\
\hline & & The driver knows the direction of the intended location \\
\hline & & The driver is able to find the fastest alternative path to the intended location \\
\hline & & $\begin{array}{l}\text { The driver is able to drive me to the intended location without asking a lot of } \\
\text { questions }\end{array}$ \\
\hline \multirow[t]{3}{*}{7} & Value-added services & The facilities provided by the online application are very diverse \\
\hline & & The facilities provided by online application suit my needs \\
\hline & & The payment transaction is very easy \\
\hline \multirow[t]{2}{*}{8} & Satisfaction & I am satisfied because the driver provides services as I expected \\
\hline & & $\begin{array}{l}\text { I am satisfied because the company provides services in accordance with what I } \\
\text { expect }\end{array}$ \\
\hline
\end{tabular}

Measurement of satisfaction was adopted from Kotler \& Keller (2009) consisting of expectation and performance of service quality provided. Finally, e-WOM measurement was adopted from Hennig-Thurau et al. (2004) distinguished through the media consumers utilized to spread positive or negative impressions. The questionnaire items employed is indicated in Table 2. 


\section{RESULT AND DISCUSSION}

Service quality is a fundamental tangible indicator given by the company to create customer satisfaction. The fundamental theory states that the capability of service quality to meet and even exceed consumer expectations will create satisfaction, and vice versa (Parasuraman et al, 1988). This positive relationship is furthermore evidenced by subsequent studies, especially on public transportation services (Lai \& Chen, 2011; Chou et al, 2015; Tsafarakis et al, 2017).

In addition to positive relationships with satisfaction, high service quality will also lead to loyalty that one of them is through Word of Mouth (WOM) (Leonnard et al., 2013; Leonnard et al, 2015). This positive relationship is evidenced in prior studies on public transportation services, particularly on buses (Ratanavaraha, 2016) and airlines (Leong, 2015). WOM is a state in which satisfied consumers spread positive impression about their experience when consuming products or services directly or as a result of actual performances that exceeds their expectations (Arndt, 1967; Wien \& Olsen, 2017). While e-WOM is the dissemination of impression that is carried out indirectly, not through face to face and not in the form of oral (Kim et al, 2017). The media utilized can be social media and chat groups. In addition to the faster information dissemination process, e-WOM also protects the personal identity of information disseminating (Abubakar et al, 2009). Differences characteristic of WOM with e-WOM allows a difference of the effect received from service quality which is one of the hypotheses to be tested. From prior studies, the effect of service quality on e-WOM on public facilities indicates a positive relationship (Li \& Wang, 2013, Ladhari \& Michaud, 2015; Tsao et al., 2015; Abubakar et al., 2017).

Consumer satisfaction after consuming goods or services will determine the consumer behavior towards the company. Satisfied customers will generate loyalty. One form of loyalty is to spread the positive impression of their experience after consuming goods and services, so as it can affect prospective customers to purchase similar products and services (Wien \& Olsen, 2017). Prior studies have proven that there is a positive effect of satisfaction on e-WOM (Yang, 2013; San-Martin, 2015).

Similar to WOM, e-WOM is one of the indirect marketing strategies undertaken by a voluntary satisfied consumer after consuming a product or service (Abubakar et al., 2017). As well as hotel or hospital services, public transportation also offers intangible services to consumers. Intangible services cause e-WOM more relevant where potential customers need reviews from other consumers before they decide on a purchase (Tsao et al., 2015). Prior studies have proven that there is a positive effect of e-WOM on consumer purchasing behavior. In fact, other studies suggest that the effect given by e-WOM is greater than WOM (Öğüt \& Onur Taş, 2012; Luo \& Zhong, 2015). Media utilized consist of websites, social media, and chat groups (Hennig-Thurau et al., 2004). 
Table 3. Evaluation of Model Validity

\begin{tabular}{|c|c|c|c|c|c|c|c|c|}
\hline Constructs & Indicators & Mean & $\begin{array}{l}\text { Loading } \\
\text { factor }\end{array}$ & $\begin{array}{c}\text { Std. } \\
\text { Deviation }\end{array}$ & T-statistics & $\begin{array}{c}\text { Composite } \\
\text { reliability }\end{array}$ & AVE & $\begin{array}{c}\text { Cronbachs } \\
\text { Alpha }\end{array}$ \\
\hline \multirow{7}{*}{$\begin{array}{l}\text { Service } \\
\text { quality }\end{array}$} & Cleanliness & 0.845 & 0.842 & 0.025 & 33.753 & 0.957 & 0.764 & 0.949 \\
\hline & Convenience & 0.776 & 0.771 & 0.028 & 27.416 & & & \\
\hline & Facilities & 0.917 & 0.921 & 0.027 & 33.983 & & & \\
\hline & $\begin{array}{l}\text { Personal } \\
\text { interaction }\end{array}$ & 0.953 & 0.956 & 0.015 & 62.271 & & & \\
\hline & Safety & 0.896 & 0.903 & 0.035 & 25.597 & & & \\
\hline & Personal skill & 0.937 & 0.940 & 0.020 & 46.674 & & & \\
\hline & $\begin{array}{l}\text { Value-added } \\
\text { services }\end{array}$ & 0.754 & 0.764 & 0.067 & 11.446 & & & \\
\hline \multirow[t]{2}{*}{ Satisfaction } & Expectation & 0.938 & 0.936 & 0.013 & 73.004 & 0.934 & 0.876 & 0.859 \\
\hline & Performance & 0.938 & 0.936 & 0.013 & 71.713 & & & \\
\hline \multirow[t]{2}{*}{ eWOM } & eWOM 1 & 0.918 & 0.914 & 0.013 & 69.795 & 0.883 & 0.791 & 0.738 \\
\hline & eWOM 2 & 0.861 & 0.864 & 0.052 & 16.648 & & & \\
\hline
\end{tabular}

The model evaluation of PLS SEM path modeling includes evaluation of convergent validity and discriminant validity. Evaluation of convergent validity includes evaluation of validity, construct reliability, and average variance extracted (AVE). While the evaluation of discriminant validity includes evaluation of cross loadings and compare the value of the square of construct correlations with AVE values. Table 3 indicated that all indicators were valid because they had loading factor values $>0.50$ and t-statistics $>2.00$. Reliability in the model was also achieved where the value of composite reliability and Cronbachs Alpha of all constructs were $>0.70$. The Average Variance Extracted (AVE) values of all constructs were also $>0.70$ therefore it could be summarized that the model had a good convergent validity.

Table 4. Evaluation of Model Discriminant Validity

\begin{tabular}{lccc}
\hline & eWOM & Satisfaction & Service Quality \\
\hline eWOM & 0.889 & & \\
Satisfaction & 0.874 & 0.936 & \\
Service Quality & 0.796 & 0.842 & 0.874 \\
\hline
\end{tabular}

Further evaluation of discriminant validity indicated that the AVE values of each indicator with its constructs were higher than that of other constructs (Fornell \& Larcker, 1981). So it could be summarized that the model had good discriminant validity (Table 4). 
Table 5. Path Coefficients of The Relationship Between Constructs Tested

\begin{tabular}{lccc}
\hline \multicolumn{1}{c}{ Path } & Coefficients & Mean & P-value \\
\hline Satisfaction -> eWOM & 0.698 & 0.701 & 0.000 \\
Service quality -> eWOM & 0.209 & 0.211 & 0.007 \\
Service quality -> Satisfaction & 0.842 & 0.846 & 0.000 \\
\hline
\end{tabular}

The structural model evaluation carried out by looking at the path coefficients and the values of $\mathrm{R}^{2}$ (Hutchinson, et al, 2009). Path coefficients and $\mathrm{R}^{2}$ were derived from performing bootstrapping techniques on the model. The findings in Table 5 and Figure 1 indicated that all hypotheses were proved. Service quality had a significant positive effect on satisfaction $(\beta=0.842)$ at $\alpha=0.00$ and against e-WOM $(\beta=0.209)$ at $\alpha=0.10$. Satisfaction also had a significant positive effect on e-WOM $(\beta=0.698)$ at $\alpha=0.00$. The $\mathrm{R}^{2}$ of satisfaction was 0.708 and the $\mathrm{R}^{2}$ of e-WOM was 0.776 . This signified that as much as $70.8 \%$ variance on satisfaction could be explained by service quality and $77.6 \%$ variance in eWOM could be explained by service quality and satisfaction. Therefore, it could be summarized that the model had a good predictive power.

Figure 1. Structural Model Test Results

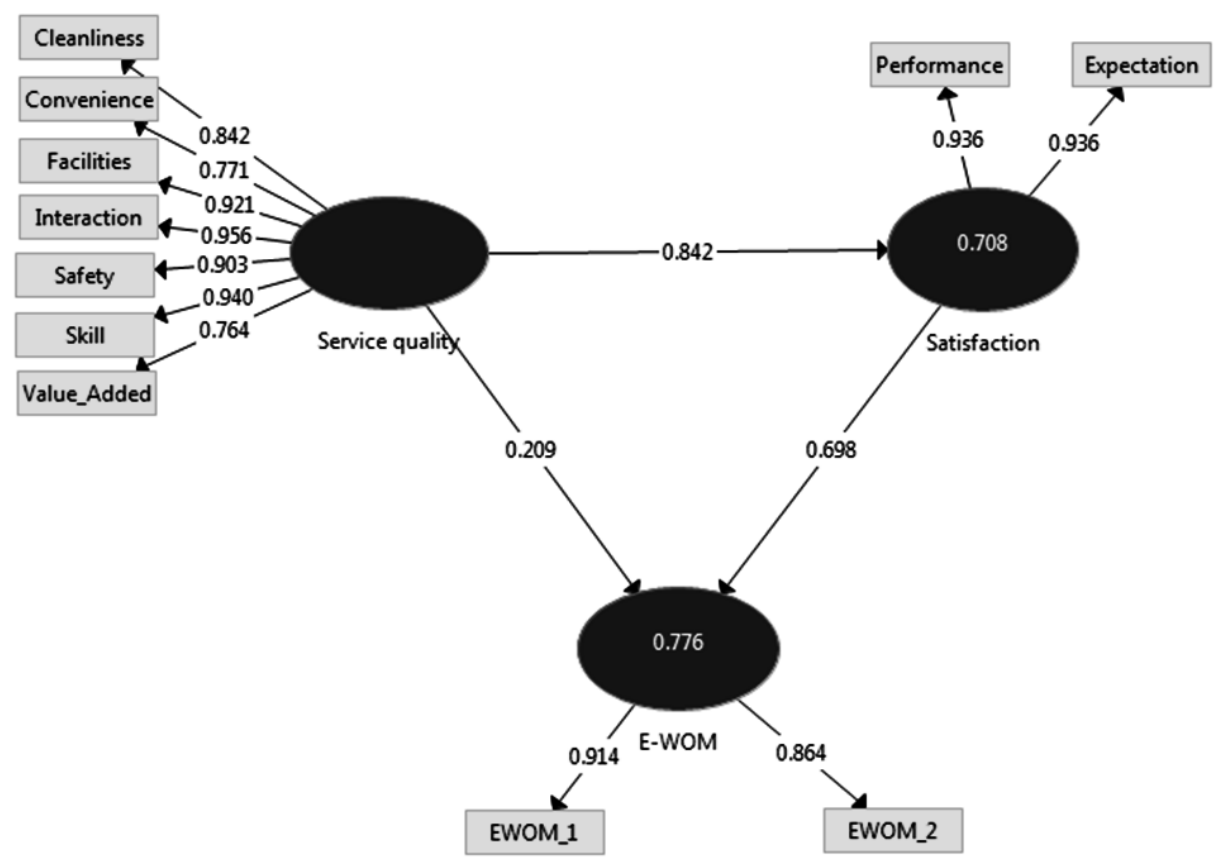

Empirical results indicated that service quality was able to explain the variance in satisfaction of $70.8 \%$. This further indicated that consumer satisfaction with motorbike taxi application was influenced by the service quality they received. This finding was no different from previous empirical results on other public transportation services such as bus, train, and airline. Furthermore, when examined for each of the indicators of service quality, the most influential indicator was personal interaction $(\beta=0.956)$, followed by personnel skills $(\beta=0.940)$, facilities $(\beta=0.921)$, safety $(\beta=0.903)$, cleanliness $(\beta=0.842)$, convenience $(\beta=0.771)$, and value-added 
services $(\beta=0.764)$. Personal interaction in this study was defined as the interaction performed by the driver to the consumer which starting at the time of order until arriving at the intended location. The highest coefficient value of personal interaction indicated that this indicator has the highest effect to consumer perception of service quality. These findings are different from the other findings from public transportation services which did not utilize online applications, where Lai \& Chen (2011) and Chou et al (2015) found that on trains, tangibles (facilities) had the highest influence. Similarly with Gupta (2017) who found similar things on airline services and Mahmoud \& Hine (2016) on bus services. Nevertheless, empirical indicates that all service quality indicators employed in this study were valid and significant as service quality indicators. Generally speaking, there was no difference regarding consumer perceptions of service quality on public transportation based on online applications. Furthermore, service quality also positively affected e-WOM directly and indirectly. The indirect effect of service quality on e-WOM was 0.587 through consumer satisfaction. These findings were consistent with prior studies (Hutchinson et al, 2009; Li and Wang, 2013; Ladhari \& Michaud, 2015; Tsao et al., 2015; Abonnel et al., 2015; Abubakar et al., 2017). Satisfaction was also known to have a positive effect on e-WOM directly. This finding was in accordance with prior studies by Yang (2013) and San-Martín (2015).

Generally, the findings of this study have some managerial implications for motorbike taxi application management. First, managers need to pay attention to the service quality provided directly by the driver to the consumers starting from the entrance order until the consumer arrives at the location they are headed. Empirical findings indicate that of all service quality indicators, the value-added provided by the online application system has the least effect compared to other indicators. Conversely, the driver interaction with the consumer consisting of physical appearance, friendliness, attitude, behavior and ability to respond to customer inquiries during the trip has higher significance effect. Therefore, human resource training and company monitoring are needed. In addition, transparent and honest feedback system also needed to be developed as one tool to evaluate driver interaction. Second, service quality and satisfaction have a positive influence on e-WOM, but the presence of satisfaction gives an indirect effect of service quality on e-WOM, which is greater than the direct impact of service quality on e-WOM which implies that satisfied consumers of the service quality will increase the dissemination of information through social media and chat groups.

\section{CONCLUSION}

From the empirical results and analysis, it is concluded that the quality of transportation application service has a significant direct positive effect on satisfaction and indirectly to e-WOM. Furthermore, from the service quality indicators, the most influential indicator is the driver's interaction with the consumer. These findings are different from public transport that does not utilize online applications where the physical facility has the highest effect on consumers' perceptions of service quality.

Some of the limitations of this study are, first respondents obtained from one major city in Indonesia. The results of the study may vary in other cities. Second, the number of respondents used is relatively small. Therefore, in further studies, the number of respondents in large quantities is highly recommended. Third, the addition of new variables such as 
fare or other types of online transportation services such as package services, household goods shopping services, and food purchasing services need to be considered for wider understanding of e-WOM predictors in a more complex way.

\section{REFRENCES}

Abubakar, A. M., Ilkan, M., Al-Tal, R. M., \& Eluwole, K. K. (2017). eWOM, Revisit Intention, Destination Trust and Gender.Journal of Hospitality and Tourism Management. Vol. 31: 220-227.

Arndt, J. (1967). Role of Product-related Conversations in The Diffusion of a New Product. Journal of marketing Research. Vol. 4 (3): 291-295.

Carreira, R., Patrício, L., Jorge, R. N., Magee, C., \& Hommes, Q. V. E. (2013). Towards a Holistic Approach to The Travel Experience: a Qualitative Study of Bus Transportation. . Transport Policy. Vol. 25: 233-243.

Chou, P. F., Lu, C. S., \& Chang, Y. H. (2014). Effects of service quality and customer satisfaction on customer loyalty in high-speed rail services in Taiwan. Transportmetrica A: Transport Science. Vol. 10(10): 917-945.

Duan, W., Gu, B., \& Whinston, A. B. (2008). Do online reviews matter?-An empirical investigation of panel data. Decision support systems. Vol. 45(4): 1007-1016.

Fornell, C., \& Larcker, D. F. (1981). Evaluating Structural Equation Models with Unobservable Variables and Measurement Error. Journal of Marketing Research. Vol. 18(1):39-50.

Gupta, H. (2017). Evaluating Service Quality of Airline Industry Using Hybrid Best Worst Method and VIKOR. Journal of Air Transport Management. doi: https://doi. org/10.1016/j.jairtraman.2017.06.001.

Hosseini, S. Y., Zadeh, M. B., \& Bideh, A. Z. (2013). Providing a Multidimensional Measurement Model for Assessing Mobile Telecommunication Service Quality (MS-qual). Iranian Journal of Management Studies. Vol. 6(2): 71-80.

Hennig-Thurau, T., Gwinner, K. P., Walsh, G., \& Gremler, D. D. (2004). Electronic Word-ofMouth via Consumer-Opinion Platforms: What Motivates Consumers to Articulate Themselves on The Internet?. Journal of Interactive Marketing. Vol. 18(1): 38-52.

Hutchinson, J., Lai, F., \& Wang, Y. (2009). Understanding The Relationships of Quality, Value, Equity, Satisfaction, and Behavioral Intentions Among Golf Travelers. Tourism management. Vol. 30(2): 298-308.

Jiang, H., \& Zhang, Y. (2016). An Investigation of Service Quality, Customer Satisfaction and Loyalty in China's Airline Market. Journal of Air Transport Management. Vol. 57: 80-88.

Kim, S., Kandampully, J., \& Bilgihan, A. (2018). The Influence of eWOM Communications: An Application of Online Social Network Framework. Computers in Human Behavior. Vol. 80: 243-254. doi: https://doi.org/10.1016/j.chb.2017.11.015.

Ladhari, R., \& Michaud, M. (2015). eWOM Effects on Hotel Booking Intentions, Attitudes, Trust, and Website Perceptions. International Journal of Hospitality Management. Vol. 46: 36-45.

Lai, W. T., \& Chen, C. F. (2011). Behavioral Intentions of Public Transit Passengers - The Roles of Service Quality, Perceived Value, Satisfaction and Involvement. . Transport Policy. Vol. 18(2): 318-325. 
Leonnard., Daryanto, H. K., Sukandar, D., \& Yusuf, E. Z. (2013). The Loyalty Model of Private University Student, Study Case: Stikom London School of Public Relation. International Journal of Information Technology and Business Management. Vol. 20(1): 91-100.

Leonnard., Daryanto, H. K., Sukandar, D., \& Yusuf, E. Z. (2015). The Loyalty Model of Private University Student. International Research Journal of Business Studies. Vol. 7(1): 55-68.

Leong, L. Y., Hew, T. S., Lee, V. H., \& Ooi, K. B. (2015). An SEM-Artificial-Neural-Network Analysis of The Relationships Between SERVPERF, Customer Satisfaction and Loyalty Among Lowcost and Full-service Airline. Expert Systems with Applications. Vol. 42(19): 6620-6634.

Li, C., \& Wang, X. (2013). The Power of E-WOM: A Re-examination of Online Student Evaluations of Their Professors. Computers in Human Behavior. Vol. 29(4): 1350-1357.

Luo, Q., \& Zhong, D. (2015). Using Social Network Analysis to Explain Communication Characteristics of Travel-related Electronic wWord-of-mouth on Social Networking Sites. Tourism Management. Vol. 46: 274-282.

Mahmoud, M., \& Hine, J. (2016). Measuring the Influence of Bus Service Quality on The Perception of Users. Transportation Planning and Technology. Vol. 39(3): 284-299.

Ögüt, H., \& Onur Taş, B. K. (2012). The Influence of Internet Customer Reviews on The Online Sales and Prices in Hotel Industry. The Service Industries Journal. Vol. 32(2): 197-214.

Parasuraman, A., Zeithaml, V. A., \& Berry, L. L. (1988). Servqual: A Multiple-item Scale for Measuring Consumer Perception. Journal of retailing. Vol. 64(1): 12 - 30.

Ratanavaraha, V., Jomnonkwao, S., Khampirat, B., Watthanaklang, D., \& Iamtrakul, P. (2016). The Complex Relationship Between School Policy, Service Quality, Satisfaction, and Loyalty for Educational Tour Bus Services: A Multilevel Modeling Approach. Transport Policy. Vol. 45: 116-126.

Reimer, T., \& Benkenstein, M. (2016). When Good WOM Hurts and Bad WOM Gains: The Effect of Untrustworthy Online Reviews. Journal of Business Research. Vol. 69(12): 5993-6001.

San-Martín, S., Prodanova, J., \& Jiménez, N. (2015). The Impact of Age in The Generation of Satisfaction and WOM in Mobile Shopping. Journal of Retailing and Consumer Services. Vol. 23: 1-8.

Şimşekoğlu, Ö., Nordfjærn, T., \& Rundmo, T. (2015). The Role of Attitudes, Transport Priorities, and Car Use Habit for Travel Mode Use and Intentions to Use Public Transportation in an Urban Norwegian Public . Transport Policy. Vol. 42: 113-120.

Tsao, W. C., Hsieh, M. T., Shih, L. W., \& Lin, T. M. (2015). Compliance with E-WOM: The Influence of Hotel Reviews on Booking Intention From The Perspective of Consumer Conformity. International Journal of Hospitality Management. Vol. 46: 99-111.

Tsafarakis, S., Kokotas, T., \& Pantouvakis, A. (2017). A Multiple Criteria Approach for Airline Passenger Satisfaction Measurement and Service Quality Improvement. Journal of Air Transport Management. doi: https://doi.org/10.1016/j.jairtraman.2017.09.010.

Wien, A. H., \& Olsen, S. O. (2017). Producing Word of Mouth-a Matter of Self-Confidence? Investigating a Dual Effect of Consumer Self-confidence on WOM. Australasian Marketing Journal (AMJ). Vol. 25(1): 38-45.

Yang, F. X. (2017). Effects of Restaurant Satisfaction and Knowledge Sharing Motivation on eWOM intentions: The Moderating Role of Technology Acceptance Factors. Journal of Hospitality \& Tourism Research. Vol. 41(1): 93-127. 